\title{
Fear of God and Its Implementation
}

\author{
Susanto Kawi \\ Sekolah Tinggi Teologi Kharisma, Indonesia
}

\begin{abstract}
Fearing God and obeying His commands will have an impact on successful life for every human being who believes in Him. The purpose of this research is to explain whether or not the concept of fearing God will have an impact on humans who believe and obey His commands. Explanation from the perspectives of the New Testament and the Old Testament sees the condition of every human being who fears God has an impact on a successful life. The method used in this research is a qualitative method, namely library research, leveraging various data sources: the Bible, interpretation of holy books and other books that discuss the fear of God, which are arranged descriptively to achieve the goals and objectives of the research. In this study it was found that in every aspect of human life, both through human actions and behavior, there are many things in life that will make people feel fear and dither, either towards other humans or against other things. Fear of God experienced by humans is an ordinary thing, but the fear of God is a respect for God, and humans will experience a successful life if we humans obey and believe in accordance with the characteristics discussed in this study.
\end{abstract}

Keywords: Fear of God, Believer's Life, lifestyle, respect, obey

\section{INTRODUCTION}

$\mathrm{B}_{\mathrm{n}}^{y}$ y looking at the story of Job, Job experienced a heartbreaking incident in his life. Job went through astonishing events after events. His first servant came to tell him that the Sheba people attacked and snatched the oxen and the donkeys and struck their guards with the blade of the sword (Job. 1:14-15). Then his second servant came and told him that the fire had caught, burned, and devoured the flock and the guards (Job. 1:16). The third servant came and told him that the Chaldeans had raided the camels and plundered them (Job. 1:17). The fourth servant came and told him that Job's sons and daughters had died when the house fell down in a hurricane (Job. 1:18-19). Through the story of Job above, what is the meaning of fearing God based on Job 1:8-9? What did Job do when finding 'incident after incident' happening in his life? Did Job grumble and leave God? How is the implementation of fear of God in daily life through the story of Job?

From the questions above, the author feels the need to explore and get to know the true meaning of fear of God based on the book of Job. The author is interested in discussing this title because of the phenomena found in God's children. When God allows a test or incident to occur, a lot of God's children actually grumble, blame God, and even leave God because what they are going through is difficult.

Through the deviant responses of God's servant, the author hopes that this article can be used as a reference and a living record for other children of God. Therefore, it is necessary to have further discussion about fear of God and its implementation in daily life based on the book of Job.

The fear of God is the most basic thing in the life of a believer. Believers cannot truly love God before they fear God. The author will discuss how believers fear God in all aspects of human life so that it will affect the words, actions, and behavior of every believer. The fear of God cannot be understood by the mind but is implanted in the heart of every believer. It is revealed by the Holy Spirit when believers receive and read the God's Word. This is one of the manifestations of the Spirit of God (Yes. 11:2-3).

The implementation in daily life, if every believer has the fear of God, they will be able to prevent stupid deeds (Psalm. 34:11-13). The fear of God will reveal the holiness of God so that every human being has the reverence and fear of God (Heb. 12:28). The author needs to understand what it really means to fear God as conveyed in God's Word. At this time, the author's understanding of the fear of God is still at the learning stage. Hopefully, by reading the existing reference books and journals and being brought in prayer, the author can better understand God's intentions so that they can know what God's will is.

\section{METHOD}

The method used in this study is a qualitative method. The researcher collected various data sources from the Bible, interpretations of holy books, other books and theological journals related to fearing God and living a successful life. The researcher then extracted from the existing data the characteristics that the God-fearing believers possessed.

This is reviewed from the Old Testament and New Testament as well as from the other previous researchers. This will answer, whether or not people who fear God will experience abundant blessings and be successful? Researcher also explores what actions Christians or believers should take. In this study, it was found that believers who have a spirit of fearing God can live in the success that God has provided.

\section{RESULTS AND DISCUSSION}

\section{Fear of God}

Proverb 1:7 (BIMK) says, "In order to gain true knowledge, one must first have respect and fear of God. Fools have no respect for wisdom and will not be taught." ${ }^{1}$ The Word of God emphasizes that the key for believers to gain wisdom is to fear God. It is in contrast to the ignorant people

\footnotetext{
${ }^{1}$ Alkitab Bahasa Masa Kini, n.d.
} 
who do not want to be taught and do not know God's infinite wisdom.

The Bible uses several words to mean fear or dread. The most common are the Hebrew "yir'a" and "pakhad" the Greek "fobos". Theologically, four main ones can be put forward; holy fear, fear of enslavement, fear of human, and being respected. ${ }^{2}$

To fear God means to feel dread (horrified) or disdain for the Highest, Exalted, Most Holy, and Almighty. "The fear of God is a holy fear, where this attitude is the result of the believer's knowledge of the living God." ${ }^{3}$ Fear in this case does not mean scary or terrible, but fear here means showing respect, obedience to God's commands and submitting to God's sovereignty. ${ }^{4}$

The fear of God is an awareness of His holiness, justice and righteousness as a partner to His love and forgiveness, namely: knowing Him and fully understanding who He is (Prov. 2:5). To fear God means to look upon Him with holy awe and reverence and honor Him as God because of His glory, holiness, majesty, and great power (Flp. 2:12)

Every believer recognizes the greatness of God, respects and lives it through the right way of life. Believers are aware that it is God who gives the breath of life, physical body, and new life for each of His people who believe in Him.

Fear of God is a healthy (positive) form of fear ${ }^{6}$. This means that humans respect God, hold on to God's decrees, and obey God's judgment for sins. Fearing God brings people closer to God, not away from Him. Christians who believe in God have a different fear from the fear the world has. The fear that believers have is more directed to "respect" for God, not fear because of a "punishment" that will be received. Many Christians have the wrong perception of what it means to fear God. Most Christians define fear of God with obedience to do God's commands is due to fear of punishment, while the true fear of God must actually be born because of relationships not because of fear of punishment, fear of God should not be because of fearing God being angry if we disobey but because we love God. ${ }^{7}$

God's Word says in 1 John 4:18, "There is no fear in love: perfect love casts out fear; because fear has punishment, and whoever fears is not perfect in love." In God it eliminates fear, not creates fear. That's why when a person who has a spirit of fearing God, when he approaches the throne of God's love there is no fear in him but peace.

\footnotetext{
${ }^{2}$ OMF, Ensiklopedia Alkitab Masa Kini Jilid II (Yayasan Komunikasi Bina Kasih, 1995).

${ }^{3}$ Ibid, n.d.

4 "Takut Akan Tuhan Adalah Permulaan Pengetahuan," n.d.

${ }^{5}$ Ibid.

${ }^{6}$ Ril Tampasigi, "Tinjauan Teologis Tentang Takut Akan Tuhan Berdasarkan Kitab Amsal Dan Implementasinya Dalam Hidup Kekristenan,” n.d.

${ }^{7}$ Peniel C. D. Maiaweng, "Tinjauan Teologis Tentang Takut Akan Tuhan Berdasarkan Kitab Amsal Dan Implementasinya Dalam Hidup Kekristenan," 2012.
}

God is the true 'Source of Blessing' so every believer needs to come to that Source of Blessing. Psalm 34:9 says, "Fear the God, you holy ones, for there is no shortage of those who fear Him!" Every believer is called a saint. God's word is yes and amen, God has 'labeled' saints for those who fear God. God's promise to His saints is to be sufficient and will not allow those who believe to be deprived because they have the spirit of fearing God.

Human being cannot have a spirit of fearing God if it is not God who gives it and human being does not ask God for it. God sends His Holy Spirit to help believers understand the true meaning of fearing God and the rewards God provides for those who believe. Believe in His Holy Spirit, believe in God who gives the Spirit to fear God, and believe in God to reward those who are willing to be molded by Him to have the Spirit of fearing God in their hearts and lives.

\section{Successful Life According to God's Measure}

For the world success is based on wealth, abundant savings, abundant wealth and treasures that will not run out until seven generations. The value of a person's success is judged by the amount of wealth to the point there is a world term saying that happiness can be bought with wealth and happiness cannot be achieved without wealth.

God warns God-fearing people in Job 15:29 (BIMK), "That man's wealth will disappear without trace; his property will be exhausted." Wealth is not eternal. Wealth is a temporary treasure that God has placed on this mortal earth. All wealth will disappear if one is not given the gift to enjoy it. Ecclesiastes 6:2, "The man who has been given riches, property and glory by God, so that he does not lack anything he desires, but has not been given the power of God to enjoy it, but someone else enjoys it! This is vanity and bitter suffering."

Success according to God's measure is depicted in Galatians 2:20, "I have been crucified with Christ and I no longer live, but Christ lives in me. The life I now live in the body, I live by faith in the Son of God, who loved me and gave himself for me" God reminds people who fear God to live in faith believing in the Lord Jesus Christ that 2000 years ago He was willing to lay down His life to atone for the sins of all mankind who believe in Him. It is good to live according to God's will, not to personal will or vision anymore.

Galatians 5:22-23 says, "But the fruits of the Spirit are: love, joy, peace, patience, kindness, generosity, faithfulness, gentleness, self-control. There is no law against those things." God guides God-fearing people to achieve success to bear the fruit of the Spirit. This is the life calling for everyone who fears God.

As the God made clear His Word in John 15:5, "I am the vine and you are the branches. Whoever abides in Me and

\footnotetext{
${ }^{8}$ Alkitab Bahasa Masa Kini.
} 
I in him, he bears much fruit, because apart from Me you can do nothing." God wants His children to live in Him who gives true success, namely helping God-fearing people to bear abundant and sweet fruit.

Jesus taught that people who fear God are different from other people who do not believe, both in their way of life, behavior and actions. Therefore, those who are successful in faith are often hated by the world. ${ }^{9}$ Luke 21:17 says, "....and you will be hated by all for my name's sake." If in the process of success you must be hated by the world, do not be discouraged because of Him, continue to pursue God's will through a life of fearing God.

\section{Understanding the Meaning of Fear of God}

1 Peter 1:15-17, "But just as he who called you is holy, so be holy in all you do; for it is written: Be holy, because I am holy. And if you call him Father, that is, He who judges all men without partiality according to their works, then live in fear as long as you stay in this world." To live in the fear of God means to live in holiness. There is a close bond of living in fear of God and living in holiness. One cannot live in fear of God but still commit the same sin or a new sin. ${ }^{10}$

As a small example, when someone who used to be a liar/slanderer is saved and has accepted the Lord Jesus as God and Savior, he is no longer living in the $\sin$ of lying/slandering. That person already knows the truth in Revelation 21:8, "But the cowardly, the unbelieving, the abominable, the murderer, the prostitute, the sorcerer, the idolater and all the liars, they shall have their share in the sea which is burning with fire and brimstone; this is the second death." Because of the truth of God's Word that had set him free, he became more and more like Christ and no longer lives in the sin of liars/slanders. ${ }^{11}$

The fear of God is related to love. Love for God and love for others. John 14:21, "Whoever has my commands and keeps them is the one who loves me. And the one who loves me will be loved by my Father, and I too will love him and will reveal myself to him." Love for God means loving God's Word which is God Himself and being doers of God's Word. Someone who loves God makes God's Word a basic need in his daily life. Not only reading but also meditating and practicing God's Word. ${ }^{12}$ James 1:22-23, "But be doers of the word, and not hearers only; for otherwise you are deceiving yourself. For if anyone only hears the word and does not act

\footnotetext{
${ }^{9}$ Andreas Nataatmadja, "Renungan Kristen," n.d.

${ }^{10}$ Rolex M. Cailing, "Fear God and Keep His Commandments: Foundation for a Relationship with God," Review \& Expositor, 2018, https://doi.org/10.1177/0034637317753666.

${ }^{11}$ Pieter G.R. de Villiers, "Fear as Dread of a God Who Kills and Abuses? About a Darker Side of a Key, but Still Forgotten Biblical Motif," HTS Teologiese Studies / Theological Studies, 2013, https://doi.org/10.4102/hts.v69i1.2018.

${ }^{12}$ Kristin Johnston Largen, "The Role of Fear in Our Love of God: A Lutheran Perspective," Dialog, 2011, https://doi.org/10.1111/j.15406385.2010.00578.x.
}

on it, he is like a man who is observing his true face in a mirror."

Love for God leads us into intimate fellowship with God. There is always a thirsty and hungry heart for dialogue with God through reading the word or through prayer. The Word of God is that God speaks to His servant, and through prayer God's servant can also speak to Him. This is an important point for believers to pay attention to. Love for God does not appear by itself but must be built through a life that is always attached to God. Love for God arises through meditating on God's Word and will always remind believers of the sacrifice of Jesus on the cross who gave His life for those who believe in Him.

Love for God brings believers to know tithe offering. The Word of God in Priesthood 27:30 says, "In the same way all tithes offered from the ground, whether from the seed on the ground or from the fruit of the trees, belong to the LORD; this is a holy offering to the LORD." All wealth and the ability to acquire wealth is from God. A person who fears God is aware that the asset he has is a trust that God has given him, namely he is the manager and God is the owner of every asset. If God asks for ten percent of all income received, then it is God's right because people who fear God realize that the treasure belongs to God. 1 Corinth 10:26 says, Because: "The earth and everything in it belongs to the Lord." Tithing is obligatory, so it must be done by people who fear God, regardless of one's condition, because God sees the obedient heart and wants to be doers of His word. As Paul G. Caram states it, "God does not want sacrifice from us if our hearts are not right with Him. ${ }^{13}$

Love for others is clearly written in Mark 12:31, "And the second commandment is: Love your fellow human as yourself. No other law is greater than these two." This is God's commandment to God-fearing people. Not only love yourself but love others as yourself.

"God hates sin and does not hates sinners." Proverbs 15:9 says, "God hates the ways of the wicked, not the wicked themselves." 1 Priesthood 25:17 says, "Do not harm one another, but fear your God, for I am the Lord your God." People who fear God stay away from evil, do not harm or deceive God, themselves, and others. As a simple example, a God-fearing person does not take what is not his or her own. People who fear God realize that taking other people's property is an act that deviates from God's Word. The Word of God in John 8:34, Jesus said to them, "Truly I say to you, everyone who sins is a slave to sin." In contrast to Godfearing people, they believe their lives have been redeemed by the precious blood of Jesus on the cross. People who fear God live the sacrifice of the Lord Jesus on the cross and stay away from evil, as well as from all crimes against God, oneself, others, family, workplace, service, even nation and state.

Luke 16:10 says, "Whoever can be trusted with very little can also be trusted with much. And whoever is dishonest

\footnotetext{
${ }^{13}$ Paul G. Caram, Kekristenan Sejati (Jakarta: Voice Of Hope, 2007).
} 
with very little will also be dishonest with much.” The Word of God clearly reminds every believer to be faithful in small things. This means that people who fear God will be brought by God to experience terrible and miraculous things. It is not allowed for people who fear God to stagnate but God promises to bring them to experience breakthroughs and success.

\section{Characteristics of People Who Fear God}

First, living in God's word (Psalm. 119:105). A person who fears God takes the Word of God as a guide for life. Through God's Word, people who fear God are increasingly taught and understand God's will in their lives. God's Word is not only read but also pondered on and practiced by people who fear God. ${ }^{14}$ Second, living in holiness (1 Pet. 1:15-17). God teaches believers to live in holiness, despite being humanly impossible, believe that God has sent His Holy Spirit to everyone who believes and fears God. Give more 'spiritual food' for our spirits, not the other way around. Third, living in love for God and love for fellow human beings (Joh. 14:21 ; Mark. 12:31). A life of loving God and a life of loving others are the characteristics of a person who fears God. ${ }^{15}$ Loving is not a compulsion but comes from the deepest heart of God-fearing people. There is a will to repay God's love through fellowship with God and social life that builds fellow human beings. Fourth, living intimately and becoming friends of God (James.2:23). The characteristic of God-fearing people is living intimately and befriend God. ${ }^{16}$ Living intimately with God has a positive impact on believers to be more similar and in the same image as God. Fifth, life being a blessing (Prov. 15:9 ; 1 Priesthood. 25:17). The characteristic of a person who fears God is that life becomes a blessing. God-fearing people realize that they were born into this world not to be a stumbling block but to be a blessing to their families, workplaces, churches, neighborhoods, and nations.

\section{The Reward of God-fearing People}

God promises to reward those who fear Him. The socalled reward is not only physical but also spiritual blessings. If every human being has the characteristics of fearing God, then humans will get blessings from holy fear, among others. ${ }^{17}$ First, providing abundant life. "Fear the GOD, o His holy people, for there is no shortage of those who fear Him!" - Psalm. 34:10. Second, provide assurance for food. " $\mathrm{He}$ gives sustenance to those who fear Him. He remembers His covenant forever." - Psalm. 111:5. Third, promise protection. "O you who fear the GOD, believe in the GOD! - He is their help and their shield." - Psalm. 115:11. Fourth, provide

\footnotetext{
${ }^{14}$ Jakub Urbaniak and Mooketsi Motsisi, "The Impact of the 'Fear of God' on the British Abolitionist Movement," Journal for the History of Modern Theology, 2019, https://doi.org/10.1515/znth-2019-0014.

${ }_{15}$ Cailing, "Fear God and Keep His Commandments: Foundation for a Relationship with God."

${ }^{16}$ Urbaniak and Motsisi, "The Impact of the 'Fear of God' on the British Abolitionist Movement."

${ }^{17}$ John Bevere, Takut Akan Tuhan (Meta Noia, 1998).
}

wisdom, understanding, and time management. "The beginning of wisdom is the fear of the GOD, and knowing the Holy One is the understanding. For by me your ages are extended, and the years of your life are added." - Psalm. 9:1011. Fifth, provide confidence and protection in the face of death. "In the fear of the GOD there is great peace, there is even protection for His children. The fear of the GOD is the source of life so that people are saved from the snares of death." - Psalm. 14:26-27. Sixth, gives peace of mind. "Better is little with the fear of the LORD than much wealth with anxiety." - Psalm. 15:16. Seventh, brings wealth, honor, and life. "The reward for humility and the fear of the LORD is wealth, honor and life." - Psalm. 22:4. Eighth, produce joy in our endeavors, and fruitful lives. "For if you do not let My people go, then I will send swarms of flies on you, your servants, your people, and your houses, so that the houses of the Egyptians, and even the land where they stand, will be full of flies." - Ex. 8:21

\section{CONCLUSION}

A believer who fears God is one who loves God and respects God's greatness. People who fear God live the sacrifice of the Lord Jesus at Calvary through the new life that God has given him. God-fearing people have faith in their lives that every sin, ancestral curse, sickness has been broken by the power of the Blood of Jesus. Characteristics of people who fear God are people who live in holiness, live in love for God and love for fellow human beings, live intimately and become friends of God, and live to be a blessing to their family, workplace, church, neighborhood, and nation.

The promises of God's Word are yes and amen. God provides rewards for His God-fearing children. The so-called rewards are not only physical blessings but also spiritual blessings. God provides abundant life, as well as assurance for food. God promises protection, provides wisdom, understanding, and time management. God provides confidence and protection in the face of death, gives peace of mind. God brings wealth, honor, and life, and produces joy in our endeavors, and fruitful lives.

\section{REFERENCES}

[1] Alkitab Bahasa Masa Kini. (n.d.).

[2] Bevere, J. (1998). Takut akan Tuhan. Jakarta: Metanoia Publishing.

[3] Browning. (2002). Kamus Alkitab. Jakarta: BPK Gunung Mulia.

[4] Cailing, R. M. (2018). Fear God and Keep His Commandments: Foundation for a Relationship with God". Review \& Expositor.

[5] Caram, P. G. (2007). Kekristenan Sejati. Jakarta: Voice of Hope.

[6] Ibid. (n.d.).

[7] Largen, K. J. (2011). The Role of Fear in Our Love of God: A Lutheran Perspective". Dialog.

[8] Maiaweng, P. C. (2012). Tinjauan Teologis Tentang Takut Akan Tuhan Berdasarkan Kitab Amsal dan Implementasinya dalam Hidup Kekristenan.

[9] Nataatmadja, A. (n.d.). Renungan Kristen.

[10] OMF. (1995). Ensiklopedia Alkitab Masa Kini Jilid II. Yayasan Komunikasi Bina Kasih.

[11] Takut Akan Tuhan Adalah Permulaan Pengetahuan. (n.d.).

[12] Tampasigi, R. (n.d.). Tinjauan Teologis tentang Takut Akan Tuhan Berdasarkan Kitab Amsal dan Implementasinya Dalam Hidup Kekristenan. 
[13] Urbaniak, J., \& Motsisi, M. (2019). The Impact of the 'Fear of God' on the British Abolitionist Movement. Journal for the History of Modern Theology.

[14] Villiers, P. G. (2013). Fear as Dread of a God Who Kills and Abuses? About a Darker Side of a Key, but Still Forgotten Biblical Motif. HTS Teologiese Studies / Theological Studies. 